$$
\begin{gathered}
\text { S sciendo International Conference KNOWLEDGE-BASED ORGANIZATION } \\
\text { Vol. XXVII }
\end{gathered}
$$

\title{
A STUDY ON THE IDENTIFICATION OF FACTORS WITH A NEGATIVE INFLUENCE ON THE TRANSFORMATION OF MILITARY AND CIVILIAN HIGHER EDUCATION INSTITUTIONS INTO "SUSTAINABLE HIGHER EDUCATION INSTITUTIONS"
}

\author{
Elisabeta-Emilia HALMAGHI, Hortensia GORSKI, Diana-Elena RANF \\ "Nicolae Bălcescu" Land Forces Academy, Sibiu, Romania \\ emmhalmaghi@gmail.com, hortensia.gorski@gmail.com, ranfd@yahoo.com
}

\begin{abstract}
Education is the foundation in the development of skills and knowledge that materialize in changing the mentality and in building a sustainable vision. The integration of the importance of sustainable development and of how a sustainable society can be built in the process of university education finally leads to the development of the entrepreneurial spirit. Accepting the changes generated by the transformation into "sustainable higher education institutions" in the university environment is influenced by internal and external factors. The article analyses the negative aspects identified in the external environment of military and civilian higher education institutions.
\end{abstract}

\section{Keywords: sustainable development, higher education institutions, PESTE technique}

\section{Introduction}

The content of the article is in line with the National Strategy for Sustainable Development of Romania 2030 and aims to identify issues that may affect the involvement and motivation of the Romanian society to transform into a sustainable society. This process of transformation must be initiated through changes in the educational sphere, starting from the premise that education is the foundation for the development of skills and knowledge, which can later materialize in a change of mentality and in building a sustainable vision.

The article funnels on military and civilian higher education institutions (hereinafter referred to as MCHEI), as students can represent the future opinion leaders by integrating information on the importance of the concept of sustainable development and building a sustainable society into their educational objectives, regardless of the field. The integration of these concepts in the university education process contributes to the formation of knowledge that develops resource management skills for the development of an entrepreneurial spirit.

Another trend of the concept of sustainability that justifies the importance of the research approach within the MCHEI is represented by the implications developed at the social level, respectively the transformation of the organizational culture by integrating the sense of responsibility regarding sustainable development. Accepting the concept of sustainability in the university environment begins with the identification of development directions, i.e. of those fundamental objectives that typify a motivating educational environment and build a state of well-being conducive to achieving the highest performances. 
The identification of research objectives for the directions of sustainable development in the university environment is preceded by an environmental analysis, able to point out and synthesize the factors of negative influence that are obstacles in the evolution and innovation of the concept. The analysis focuses on the negative aspects identified from the external environment of the MCHEI to cover the whole range of elements that will form the premises on which the research on the influence of organizational culture on organizational behavior in sustainable development management (hereinafter referred to as SDM) will be based.

The research methods are: bibliographic study of the literature on sustainable development and the PESTE technique as a management method.

\section{Literature review}

The concept of "sustainable development" was coined in the "World Conservation Strategy" in 1981, was later taken up in the Brundtland Report in 1987 and in some United Nations documents, such as "Caring for the Earth", in 1991, successor of the "World Conservation Strategy". At that time, sustainable development (hereinafter referred to as SD) was seen as a solution to the problem of continuous environmental degradation and of the ecological crisis resulting from the intense industrial exploitation of natural resources and was considered to be the result of an integrated approach, in which "environmental protection and long-term economic growth are considered complementary and mutually dependent" [1]. The report defined SD as "development that meets the needs of the present generation, without compromising the ability of future generations to meet their own needs"[2]. In other words, each generation satisfies its own economic, social, and/or demographic needs without leaving to future generations the task of bearing the debts incurred by the previous generation: financial - long-term loans, external and internal; demographic population growth beyond the capacity supported by existing resources; social - a decrease of amounts invested in human resources; environmental - a decrease/depletion of renewable and nonrenewable natural resources and/or pollution of environmental factors [3]. SD shows that economic and social progress can be made without compromising the Earth's natural balance. The main concern of SD supporters is to prevent the deterioration of the quality of the environment and to keep it in the best possible conditions for those to come. Nowadays, the concept of SD has "matured": when it appeared, it was focused on the conservation of the environment; now, it is based on the balance of its dimensions: economic, social, and environmental. "True sustainability involves applying systems thinking to anticipate the unintended consequences that may occur when the whole system is not taken into account" [4]. The adoption of the concept of SD was paralleled with the approval of the concept of education that comes in support of sustainable development[5]. Education for sustainable development (hereinafter referred to as ESD) must "become an integral part of the quality of education inherent in the concept of lifelong learning" [6] and aims to develop those skills that lead people to reflect on their own actions, taking into account the social, cultural, economic and environmental impact and is an interdisciplinary approach to learning that covers the integrated social, economic and environmental dimensions of the formal and informal curriculum. This type of education was not initiated by specialists in the field of education but came from international political and economic forums [7]. The promotion of the concept of ESD and the adoption in the European Commission, in 2010, of the Strategy "Europe 2020. A European strategy for smart, green and 
inclusive growth", led to the approach of education "as a process that prepares young generations for the challenges of the future and takes place throughout life, encouraging innovation, meritocracy, constructive critical thinking, curiosity, conduct and emancipation". [8]

The main objectives of the Europe 2020 Strategy are to create more sustainable jobs and ensure better living conditions. In order to achieve these objectives, three interconnected axes (priorities) have been proposed [9]:

- smart growth - by moving to sustainable economic development, based on knowledge and innovation;

- sustainable growth - by initiating and supporting the use of the available resources in the economy, in an efficient, ecological and competitive way;

- inclusive growth - by initiating and supporting an economy in which employment has a high rate and which guarantees the achievement of social and territorial cohesion.

3. Transformation of factors/elements with a negative influence on the implementation of the concept of sustainable development in research directions

Through its educational and research offer adapted to the needs of society, MCHEI generates and transmits knowledge to society. Through education, people acquire "the skills needed to thrive in the new sustainable economy, working in areas such as renewable energy, smart agriculture, forest rehabilitation, resourceefficient city design and sound management of healthy ecosystems" [10]. A strong university education system in which the teaching system is constantly adapted to socio-economic realities and "computers, the internet, the web, mobile devices, and other digital media are increasingly important technologies" [11] facilitates access to the opportunities of the labor market, improves the health system and supports the resilience of communities, which results in economic growth in a way that can strengthen and accelerate these processes.

Given that higher education "shapes human behavior and cultural expectations" [12], it is necessary for higher education institutions to assume their role in raising society's awareness of the need to implement the concept of sustainable development. A first step in assuming this role is to change the MCHEI into sustainable MCHEI and identify research directions that can significantly contribute to changing the mentality on the concept of sustainable development in the university environment to ensure the sustainability of the whole process carried out on the three pillars of sustainable development (economic, social, environmental), and more than that, identifying ways to achieve the changes at the level of organizational culture.

This change of mentality is later disseminated in the society through the opinion formers in which the students/master students/doctoral students materialize and trigger/favor the construction of a culture of regional and national sustainable development.

The student as an opinion former acts in two directions:

- first of all, as a citizen, through the behavior adopted in the society and the involvement in the socio-cultural life of the community;

- secondly, as an employee, after integration in the workplace, where through their behavior and habits acquired during studies, and through accumulated knowledge, transmits and creates the conditions conducive to the sustainable development of the organization.

In order to identify the problems that arise when the MCHEI adopts SDM and becomes sustainable MCHEI, the PESTE technique was applied. 
Table 1 presents the general external environment factors that are considered specific to military higher education institutions (hereinafter MHEI) and civilian higher education institutions (hereinafter CHEI).

Table 1 General external environment factors specific to MHEI and CHEI

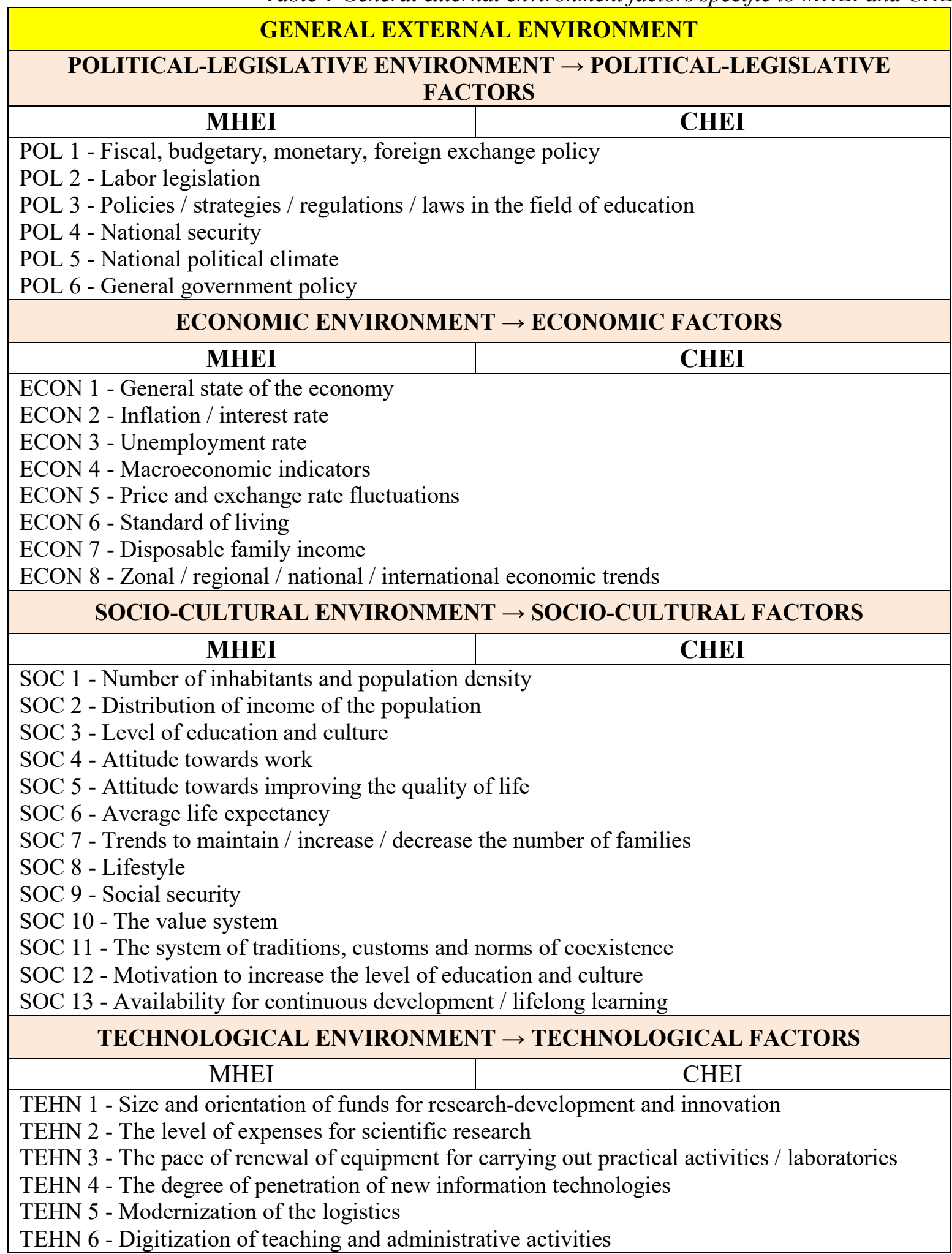




\begin{tabular}{|c|c|}
\hline $\begin{array}{l}\text { TEHN } 7 \text { - Modeling-simulation of military } \\
\text { actions } \\
\text { TEHN } 8 \text { - Age of military equipment and } \\
\text { technique } \\
\text { TEHN } 9 \text { - The level of professional training of } \\
\text { military instructors }\end{array}$ & $\begin{array}{l}\text { TEHN } 10 \text { - Regulations on polluting technologies } \\
\text { used in carrying out practical activities / } \\
\text { laboratories }\end{array}$ \\
\hline \multicolumn{2}{|c|}{ ECOLOGICAL ENVIRONMENT $\rightarrow$ ECOLOGICAL FACTORS } \\
\hline MHEI & CHEI \\
\hline \multicolumn{2}{|c|}{$\begin{array}{l}\text { ECOL } 1 \text { - Environmental protection legislation } \\
\text { ECOL } 2 \text { - Quality of environmental factors } \\
\text { ECOL } 3 \text { - Chemicals used for practical works and discharged into the sewage }\end{array}$} \\
\hline $\begin{array}{l}\text { ECOL } 4 \text { - Impairment of environmental factors } \\
\text { during training / field exercises } \\
\text { ECOL } 5 \text { - Forms of relief }\end{array}$ & $\begin{array}{l}\text { ECOL } 6 \text { - Impairment of environmental factors } \\
\text { during practical work in CHEI microfactories }\end{array}$ \\
\hline
\end{tabular}

In order to transform the negative elements into research directions, a correlation was made between the possible obstacles that stand in the way of SDM implementation in the MCHEI and the factors with a negative influence from the external environment that can generate them.

Table 2 Problems identified at the MCHEI and external factors that may generate them

\begin{tabular}{|c|c|c|}
\hline \multirow{2}{*}{$\begin{array}{l}\text { Possible obstacles / } \\
\text { Research premises }\end{array}$} & \multicolumn{2}{|c|}{ Factors with a negative influence on the environment } \\
\hline & MHEI & $\mathbf{C H}$ \\
\hline $\begin{array}{l}\text { Faculty's knowledge of the } \\
\text { concepts of "sustainable } \\
\text { development" and "sustainable } \\
\text { development management" }\end{array}$ & \multicolumn{2}{|c|}{$\begin{array}{l}\text { POL } 3 . \\
\text { ECON } 6 . \\
\text { SOC } 3 ; \text { SOC 10; SOC 11; SOC 12; SOC } 13 .\end{array}$} \\
\hline $\begin{array}{l}\text { Existence at the MCHEI level of a } \\
\text { sustainable development strategy }\end{array}$ & \multicolumn{2}{|c|}{$\begin{array}{l}\text { POL 1; POL 3; POL } 6 . \\
\text { ECON 5; ECON 6; ECON } 8 \text {. } \\
\text { SOC 3; SOC 4; SOC 5; SOC 9; SOC 10; SOC } 11 ; \\
\text { SOC 12; SOC 13. } \\
\text { TEHN 1; TEHN 2; TEHN 3; TEHN 4; TEHN 5; TEHN } 6 . \\
\text { ECOL 1. }\end{array}$} \\
\hline $\begin{array}{l}\text { Availability at the MCHEI level } \\
\text { to initiate changes to help } \\
\text { implement SDM }\end{array}$ & \multicolumn{2}{|c|}{$\begin{array}{l}\text { POL } 1 \text {; POL 3; POL 5; POL } 6 . \\
\text { ECON 1; ECON 2; ECON 4; ECON 5; ECON 6; ECON } 8 . \\
\text { SOC 2; SOC 3; SOC 4; SOC 5; SOC 8; SOC 9; SOC } 10 \text {; } \\
\text { SOC 11; SOC 12; SOC } 13 . \\
\text { TEHN 1; TEHN 2; TEHN 3; TEHN 4; TEHN 5; TEHN } 6 . \\
\text { ECOL 1; ECOL } 2 .\end{array}$} \\
\hline \multirow[t]{2}{*}{$\begin{array}{l}\text { Expected effects of SDM } \\
\text { implementation in MCHEI }\end{array}$} & \multicolumn{2}{|c|}{ 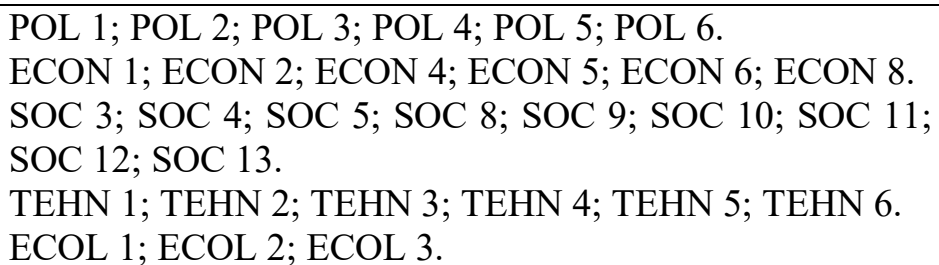 } \\
\hline & $\begin{array}{l}\text { TEHN 7; TEHN 8; TEHN } 9 . \\
\text { ECOL 4; ECOL } 5 .\end{array}$ & $\begin{array}{l}\text { TEHN } 10 . \\
\text { ECOL } 6 .\end{array}$ \\
\hline Obstacles to implementation & \multicolumn{2}{|c|}{$\begin{array}{l}\text { POL 1; POL 2; POL 3; POL 4; POL 5; POL } 6 . \\
\text { ECON 1; ECON 2; ECON 4; ECON 5; ECON 6; ECON } 8 \text {. } \\
\text { SOC 3; SOC 4; SOC 5; SOC } 8 \text {; SOC 9; SOC 10; SOC } 11 ; \\
\text { SOC } 12 ; \text { SOC } 13 \text {. }\end{array}$} \\
\hline
\end{tabular}




\begin{tabular}{|c|c|c|}
\hline \multirow{2}{*}{$\begin{array}{l}\text { Possible obstacles / } \\
\text { Research premises }\end{array}$} & \multicolumn{2}{|c|}{ Factors with a negative influence on the environment } \\
\hline & MHEI & CHEI \\
\hline & \multicolumn{2}{|c|}{$\begin{array}{l}\text { TEHN 1; TEHN 2; TEHN 3; TEHN 4; TEHN 5; TEHN } 6 . \\
\text { ECOL 1; ECOL 3. }\end{array}$} \\
\hline & $\begin{array}{l}\text { TEHN 7; TEHN 8; TEHN } 9 . \\
\text { ECOL } 4\end{array}$ & $\begin{array}{l}\text { TEHN } 10 . \\
\text { ECOL } 6 .\end{array}$ \\
\hline $\begin{array}{l}\text { Opening of the MCHEI for } \\
\text { (national and international) } \\
\text { partnerships in the field of SD }\end{array}$ & \multicolumn{2}{|c|}{$\begin{array}{l}\text { POL 1; POL 3; POL 4; POL 5; POL } 6 . \\
\text { ECON 1; ECON 2; ECON 4; ECON 5; ECON 6; ECON } 8 . \\
\text { SOC 3; SOC 4; SOC 5; SOC 8; SOC 9; SOC 10; SOC 11; } \\
\text { SOC 12; SOC 13. } \\
\text { TEHN 1; TEHN 2; TEHN 3; TEHN 5; TEHN } 6 . \\
\text { ECOL 1. }\end{array}$} \\
\hline \multirow[t]{2}{*}{$\begin{array}{l}\text { Transformation of MCHEI into } \\
\text { "Green Universities" (knowledge } \\
\text { of the concept, measures that can } \\
\text { be taken for transformation, } \\
\text { directions of development, } \\
\text { implementation of SDM) }\end{array}$} & \multicolumn{2}{|c|}{$\begin{array}{l}\text { POL 1; POL 2; POL 3; POL 4; POL 5; POL } 6 . \\
\text { ECON 1; ECON 2; ECON 4; ECON 5; ECON 6; ECON } 8 . \\
\text { SOC 3; SOC 4; SOC 5; SOC 8; SOC 9; SOC 10; SOC 11; } \\
\text { SOC 12; SOC 13. } \\
\text { TEHN 1; TEHN 2; TEHN 3; TEHN 4; TEHN 5; TEHN } 6 . \\
\text { ECOL 1. }\end{array}$} \\
\hline & TEHN 7; TEHN 8; TEHN 9. & TEHN 10. \\
\hline $\begin{array}{l}\text { Involvement of the faculty in the } \\
\text { implementation of SDM } \\
\text { (modification of internal } \\
\text { regulations, subject sheets, } \\
\text { interdisciplinary approach to SD } \\
\text { and SDM, introduction of new } \\
\text { disciplines addressing SD and } \\
\text { SDM, establishment of new } \\
\text { university specializations to train } \\
\text { specialists in SD and SDM) }\end{array}$ & \multicolumn{2}{|c|}{$\begin{array}{l}\text { POL 2; POL } 3 . \\
\text { ECON 1; ECON } 8 . \\
\text { SOC } 3 \text {; SOC } 4 \text {; SOC 5; SOC 10; SOC 12; SOC } 13 \\
\text { TEHN 1; TEHN 2; TEHN 3; TEHN 4; TEHN 5; TEHN } 6 .\end{array}$} \\
\hline $\begin{array}{l}\text { Motivating faculty member to } \\
\text { participate in the implementation } \\
\text { of SDM }\end{array}$ & \multicolumn{2}{|c|}{$\begin{array}{l}\text { POL 2; POL } 3 . \\
\text { SOC 3; SOC 4; SOC 5; SOC 10; SOC 12; SOC } 13 . \\
\text { TEHN 1; TEHN 2; TEHN 5; TEHN } 6 .\end{array}$} \\
\hline $\begin{array}{l}\text { The influence that the } \\
\text { implementation of SDM will have } \\
\text { on the organizational culture and } \\
\text { behavior }\end{array}$ & \multicolumn{2}{|c|}{ SOC 3; SOC 4; SOC 5; SOC 10; SOC 12; SOC 13.} \\
\hline $\begin{array}{l}\text { The influence that organizational } \\
\text { culture will have on SDM }\end{array}$ & \multicolumn{2}{|c|}{ SOC 3; SOC 4; SOC 5; SOC 10; SOC 12; SOC 13.} \\
\hline
\end{tabular}

In order to support the MCHEI in the implementation of the SDM and their transformation into "sustainable higher education institutions", a ranking of environmental factors was established, according to the extent of their negative manifestations and based on the information in Table 2.

Table 3 Ranking of the environmental factors according to the extent of their negative manifestations

\begin{tabular}{|l|c|}
\multicolumn{1}{|c|}{ Factor } & Frequency \\
\hline SOC 3 - Level of education and culture & 11 \\
\hline SOC 10 - System of values & 11 \\
\hline SOC 12 - Motivation to increase the level of education and culture & 11 \\
\hline SOC 13 - Availability for continuous development / lifelong learning & 11 \\
\hline
\end{tabular}




\begin{tabular}{|c|c|}
\hline Factor & Frequency \\
\hline SOC 4 - Attitude towards work & 10 \\
\hline SOC 5 - Attitude towards improving the quality of life & 10 \\
\hline POL 3 - Policies / strategies / regulations / laws in the field of education & 9 \\
\hline $\begin{array}{l}\text { TEHN } 1 \text { - Size and orientation of funds for research and development and } \\
\text { innovation }\end{array}$ & 8 \\
\hline TEHN 2 - The level of expenses for scientific research & 8 \\
\hline TEHN 5 - Modernization of the logistics & 8 \\
\hline TEHN 6 - Digitization of teaching and administrative activities & 8 \\
\hline ECON 6 - Standard of living & 7 \\
\hline ECON 8 - Zonal / regional / national / international economic trends & 7 \\
\hline SOC 11 - The system of traditions, customs and norms of coexistence & 7 \\
\hline $\begin{array}{l}\text { TEHN } 3 \text { - The pace of renewal of equipment for carrying out practical } \\
\text { activities / laboratories }\end{array}$ & 7 \\
\hline POL 1 - Fiscal, budgetary, monetary, foreign exchange policy & 6 \\
\hline POL 6 - General government policy & 6 \\
\hline ECON 1 - General state of the economy & 6 \\
\hline ECON 5 - Price and exchange rate fluctuations & 6 \\
\hline SOC 9 - Social security & 6 \\
\hline TEHN 4 - The degree of penetration of new information technologies & 6 \\
\hline ECOL 1 - Environmental protection legislation & 6 \\
\hline POL 2 - Labor legislation & 5 \\
\hline POL 5 - National political climate & 5 \\
\hline ECON 2 - Inflation / interest rate & 5 \\
\hline ECON 4 - Macroeconomic indicators & 5 \\
\hline SOC 8 - Lifestyle & 5 \\
\hline POL 4 - National security & 4 \\
\hline TEHN 7 - Modeling-simulation of military actions & 3 \\
\hline TEHN 8 - Age of military equipment and technique & 3 \\
\hline TEHN 9 - The level of military instructors' professional training & 3 \\
\hline $\begin{array}{l}\text { TEHN } 10 \text { - Regulations on polluting technologies used in carrying out practical } \\
\text { activities / laboratories }\end{array}$ & 3 \\
\hline ECOL 2 - Quality of environmental factors & 2 \\
\hline ECOL 3 - Chemicals used for practical work and discharged into the sewage & 2 \\
\hline ECOL 4 - Impairment of environmental factors during training / field exercises & 2 \\
\hline $\begin{array}{l}\text { ECOL } 6 \text { - Impairment of environmental factors during practical work in CHEI } \\
\text { microfactories }\end{array}$ & 2 \\
\hline SOC 2 - Distribution of income of the population & 1 \\
\hline ECOL 5 - Forms of relief & 1 \\
\hline ECON 3 - Unemployment rate & 0 \\
\hline ECON 7 - Disposable family income & 0 \\
\hline SOC 1 - Number of inhabitants and population density & 0 \\
\hline SOC 6 - Average life expectancy & 0 \\
\hline SOC 7 - Trends to maintain / increase / decrease the number of families & 0 \\
\hline
\end{tabular}

The ranking of environmental factors according to the extent of their negative manifestations, leads to the observation that some of the socio-cultural factors (Level of education and culture, System of values, Motivation to increase the level of 
education and culture, Availability for continuous development / lifelong learning have the greatest negative impact. On the other hand, economic factors (Unemployment rate, Family disposable income) and socio-cultural factors (Population and population density, Average life expectancy, Trends of maintaining/ increasing / decreasing the number of families) have no influence.

\section{Conclusions}

The transformation of the MCHEI into "sustainable higher education institutions" will not take place "overnight" and is "dependent" on faculty members. The higher the level of education and culture, the value system, the motivation, and availability for their lifelong learning, the better-prepared the faculty, and more willing to constantly update their knowledge to be transmitted to students and to use multimedia technologies in their teaching activities. Consequently, these factors can represent future research directions to identify ways to mitigate the effects of their negative influences.

SDE requires the reorientation of the current teaching model, in which students only receive the information, towards an interactive model that will determine the modification of the syllabus, of the teaching methods, but also the teacher-student relationship.

\section{Acknowledgements}

The paper is part of the research for the doctoral thesis on "The influence of organizational culture on organizational behavior in the management of sustainable development."

\section{References List}

[1] ***. Strategia Naţională pentru Dezvoltare Durabilă a României Orizonturi 2013-20202030. Bucureşti. 2008. Available from: http://www.mmediu.ro/beta/wpcontent/uploads/2012/06/2012-06-12_dezvoltare_durabila_snddfinalromana2008.pdf. Accessed in 30.01.2021.

[2] World Commission on Environment and Development, Report of the World Commission on Environment and Development: Our Common Future. Page 41. Available from: https://sustainabledevelopment.un.org/content/documents/5987ourcommon-future.pdf. Accessed in 30.01.2021.

[3] World Commission on Environment and Development, Report of the World Commission on Environment and Development: Our Common Future. Page 41. Available from: https://sustainabledevelopment.un.org/content/documents/5987ourcommon-future.pdf. Accessed in 30.01.2021.

[4] Babe G. Foreword to Chris Laszlo, Nadya Zhexembayeva, Embedded Sustainability: The Next Big Competitive Advantage. London and New York: Rutledge Taylor and Francis Group. 2017. p. IX.

[5] Hopkins, C., McKeown, R. Education for sustainable development: an international perspective. In: Tilbury, D., Stevenson, R.B., Fien, J. and Schreuder, D. (eds.). Education and Sustainability: Responding to the Global Challenge. Commission on Education and Communication. Gland, Switzerland, and Cambridge, U.K., IUCN, 2002, p. 14.

[6] ***. Strategia națională pentru Dezvoltarea Durabilă a României 2030. 2020. Page 38. Available from: http://dezvoltaredurabila.gov.ro/web/wpcontent/uploads/2020/10/Strategia-nationala-pentru-dezvoltarea-durabila-a-Romaniei2030_002.pdf. Accessed in 12.02.2021. 
[7] Halmaghi, E.E., Moșteanu, R. The Premises of Appearance of the Education Concept for Sustainable Development. The $25^{\text {th }}$ International Conference "The Knowledge-Based Organization". Conference Proceedings 1 - Management and Military Sciences. Sibiu: „Nicolae Bălcescu” Land Forces Academy Publishing House. 2019. Pages 241-244.

[8] ***. Strategia naţională pentru Dezvoltarea Durabilă a României 2030. 2020. Page 37. Available from: http://dezvoltaredurabila.gov.ro/web/wpcontent/uploads/2020/10/Strategia-nationala-pentru-dezvoltarea-durabila-a-Romaniei2030_002.pdf. Accessed in 12.02.2021.

[9] Ministerul Educației și Cercetării Științifice. Strategia Europa 2020. Available from: http://oldsite.edu.ro/index.php/articles/c851/. Accessed in 08.02.2021. Comisia Europeană, Comunicare a Comisiei. Europa 2020. O strategie europeană pentru o creștere inteligentă, ecologică și favorabilă incluziunii. Buxelles. 2010. Pages 5, 12. Available from: https://eur-lex.europa.eu/legalcontent/RO/TXT/PDF/?uri=CELEX:52010DC2020\&from=en. Accessed in 08.02.2021.

[10] Bokova I., Figueres C. Why education is the key to sustainable development. Published in 19 May 2015. Available from: https://www.weforum.org/agenda/2015/05/whyeducation-is-the-key-to-sustainable-development/. Accessed in 05.05.2021.

[11] Martinescu-Bădălan, F. Efectele pandemiei COVID-19 asupra efectuării activităţilor fizice. În: Ranf, D.E., Bucovețchi, O.M.C., Badea, D. Managementul sustenabilității și sustenabilitatea managerială între paradigme clasice și moderne. Sibiu: Editura Academiei Forțelor Terestre „Nicolae Bălcescu“. 2021. Page 144.

[12] Godemann, J., Bebbington, J., Herzig, C., Moon, J. Higher Education and Sustainable Development. Exploring Possibilities for Organisational Change. Accounting, Auditing \& Accountability Journal, Emerald Group Publishing. Vol. 27(2). February 2014. Pages 218-233. Available from:

https://www.researchgate.net/publication/259573757_Higher_Education_and_Sustainab le_Development_Exploring_Possibilities_for_Organisational_Change. Accessed in 07.02.2021.

[13] Based on Diana Elena RANF, Bazele managementului: aplicaţii, studii de caz. Sibiu: Editura Academiei Forțelor Terestre „Nicolae Bălcescu“. 2020. Pages 64-65. 